\title{
Preface: Doing the Jewish Family
}

Several years ago, when Andy Bush (one of the coeditors of this series and the author of its keynote volume) told me about Key Words in Jewish Studies, I responded immediately that if I ever got up the courage to write a volume for the series, it would be on the Jewish family. (And if those weren't my exact words, please let me pretend they were.) "Family" wasn't the key word that I selected from a list prepared in advance by Andy, by Marlie Wasserman (our acquiring editor for this series at Rutgers University Press), or by anyone else. It was the word that came to my mind. That is to say, this series might not have had a book on the Jewish family if Andy had not asked me to contribute a volume.

Or more modestly and perhaps also more likely, it would have had one by a different author. That would surely have been a very different book from this one. As will become very clear, this is by no means the book on the Jewish family. Both the topic and the title are well represented in recent English-language Jewish studies. If nothing else, that fact does support the notion that "family" really is a key word in Jewish studies.

All of this is to say that while I hope you find this book thorough, lucid, and convincing, at least in its main outlines, still, it is nothing more or less than my best take after (as I now realize) some thirty years during which its topic was on my mind in one form or other. It's not an encyclopedia, or a history, or even an overview. It's an articulation, an utterance (rather long-winded, perhaps), in an ongoing conversation. The more I've worked on it, the more aware I've become of the necessity to mark this clearly as a report on what I've learned and considered so far. Thus this 
work represents an invitation to the reader to join me, and all the scholars I rely on and introduce here, as we continue the investigation and the accompanying discussion. Accordingly, the book is organized somewhat loosely by topic and may not be easily reducible to a handy study outline. I hope I've made up for that by explaining many of the underlying present-day concerns, both social and intellectual, that are shared by scholars in various disciplines as they try to understand, contrast, and compare the family patterns of Jews in many different times and places with their fellow Jews and with the non-Jewish populations among whom they live.

The fact of contingency - that things turned out this way, but might, from the perspective of an earlier moment, have turned out that way, instead — can be papered over in scholarly jargon, but it shouldn't be. That question of contingency is certainly pertinent to the question of how we think about, talk about, and construct our various images of the Jewish family. It is closely related to the kind of anxiety that scholars experience as uncertain relationships between the accounts of Jewish families they produce in their professional work, the notions of Jewish family circulating in Jewish communities and beyond, and the way things really are or were. That anxiety is reflected in terms that appear within several titles you will find in the bibliography: David Kraemer's The Jewish Family: Metaphor and Memory, Paula Hyman's "The Modern Jewish Family: Image and Reality," and Mitchell Hart's Jewish Blood: Metaphor and Reality in History, Religion, and Culture.

However phrased, we need to keep the poles of this anxiety both separate and joined together: separate, because scholarship in significant ways has different rules and outcomes than the everyday circulations of folklore, especially where the scholarship and folklore have to do with the characterization of distinctive social groups living in complex relation with members of other groups; and together because it is in and through language writ large - the human capacity for complex systems of signsthat we create kinship or family as something encompassing but much 
more complex than bare biological reproduction (as if such a thing were ever possible in any case).

Hence, this book draws on perspectives from various disciplinary approaches: anthropology, history, sociology, literary history. These may complement each other nicely, but at times their juxtaposition may be confusing: if so, I apologize. This book also tries to draw on both rhetorical or narratological approaches (those that place great emphasis on how we and those about whom we write create and view the objects of our research) and empirical studies (those that focus on "what's actually going on").

Some more caveats are necessary. Heaven knows there have been and continue to be plenty of poor Jews; indeed, like most humans everywhere since poverty was invented, the majority of Jews throughout history have doubtless been poor folk. Wealthier Jews are overrepresented here, especially in the historical sections, perhaps because they had greater choice and range of action in creating their own family patterns and more opportunities to come closer to the observance of ideal rules, but more immediately because they tended to leave more and better written records. I have drawn almost exclusively on English-language sources, although, to be sure, much pertinent scholarship is to be found in Hebrew and in various European languages. I focus disproportionately, although by no means exclusively, on Ashkenazi (Central and especially East European) Jews and on Jews in the United States. Moreover, these two emphases reinforce each other, because the majority (but by no means all) of the Jewish population in the United States today traces its ancestry to Ashkenazi families.

I include a brief look at some of the discourses and practices concerning the transformation of the Jewish family and the reproduction of Jewish generations in the state of Israel. But the entanglements there of state structures with ethnicity and kinship are so different from the conditions of the Diaspora yesterday and today that no pretense at a more comprehensive account of the Jewish family in Israel is made here. Nor, for that 
matter, does this book address the suffering and agency of Jews as family members during the Nazi genocide-though at one point, my survey comes close to the brink, discussing Nazi Germany in the I930s.

Throughout, I seek a balance between the description of patterns that are distinctively and consistently Jewish and the reality of changing circumstances and mores. The former concern leads me to focus on the kind of Judaism generally called "rabbinic" - a formation that regards as authoritative the late-antique discourses of those scholars who are collectively known as "the rabbis" and whose attributed voices are recorded in the Talmud and related texts. From the central Middle Ages until the Enlightenment, and still today for many Jews, rabbinic law and lore have been the core of Jewishness. Indeed, this book will have little or nothing to say about competing or alternative "Judaisms" (nor, indeed, about the recent contention that even the term "Judaism" is an anachronism when applied to ancient times), at least until the liberal movements of modernity. However, by specifying a focus on rabbinic Judaism, I do not mean to designate that formation as "normative Judaism." Ultimately (though this formulation, too, is problematic), it is safer to start from the assumption that what's "Jewish" is what people who are called Jews do and say.

This book may be or seem to be something of a smorgasbord: there is an embarrassment of rich resources and thought on this topic, evidence of the perceived centrality of family to any notion of common Jewish identity throughout periods and regions and as a core area of human experience where we can show once again how Jews in their difference are like their human fellows. In order to present a decent sample of this rich research, I have often chosen to draw only on selected central topics in various works referred to here, such as the levirate marriage as a strategy of continuity (Weisberg 2009) or the perceived social hierarchies among contemporary Hasidic families (Fader 2009) or the link between circumcision and maternity (Derrida 1993) or the abortion debate in the Israeli Knesset (Sered 2000). Nor will these always be what the authors of 
these works themselves announce as their most urgent messages. My aim here is dual: to build a composite, rich, but by no means exhaustive picture of the complexities involved in any notion of "the Jewish family" and to tempt you to read and to think further, drawing on the sources presented here and others. Meanwhile, hold on tight and keep your head: this is going to be a fast ride through space, language, bodies, and time. 



\section{JEWISH FAMILIES}


The Sages taught: The human was created in the singular, and why? So that the Sadducees would not say there are many powers in Heaven. Another interpretation: On account of the righteous and on account of the evildoersso that the righteous would not say, "We are the children of a righteous one" and the evildoers say, "We are the children of an evildoer." Another interpretation: On account of the families, so that families would not strive against each other. And if even now, when humanity was created as singular, they strive-how much more so if they had been multiply created?

The Sages [also] taught: [The creation of the human in the singular] was to show forth the greatness of the Supreme King of kings, the Holy One, blessed be He. For if a man mints many coins from one mold, they are all alike, but the Holy One, blessed be He, fashioned all humans in the mold of the first, and not one resembles the other, for it is written, It is changed as clay under the seal and they stand as a garment. 